\title{
Big data and tourism planning
}

\author{
Yang Yang $^{1}$ D . Jason L. Stienmetz ${ }^{2}$
}

Received: 15 November 2018 / Accepted: 17 November 2018 / Published online: 26 November 2018 (c) Springer-Verlag GmbH Germany, part of Springer Nature 2018

The focus of this special section of the Journal of Information Technology \& Tourism is on the innovative applications and analysis of big data for tourism planning, which are expected to have vital implications for destination management and to bring unique advantages to tourism planning practices. In this IT era, tourists and the tourism industry heavily embrace different information and communication technologies; as a result, various sources of big data have emerged to provide a large amount of real-time data with space-time tags on tourism activities (Pan and Yang 2016). Some typical examples of these data sources include online search queries (Xiang 2010), social media data (Huertas and Marine-Roig 2016), cell-phone roaming data (Hardy et al. 2017), and credit card transaction data (De Montjoye et al. 2015). In recent years, both practitioners and tourism researchers have begun to enthusiastically analyze these data sources to generate business insights, and a large number of research efforts have confirmed the usefulness of big data in tourism management (Mariani et al. 2018). Furthermore, with the growth of the Internet of Things and the big data collected from various "digital sensors", it is envisaged that big data methodologies will continue to gain importance as researchers and practitioners have increasing opportunity to capture abundant information related to all stages of travel.

The first paper in this special section details a big data driven approach to providing customized event recommendations for tourists. Based on open data, the paper develops a framework to match events and hotel bookings based on geographic proximity. This framework ultimately improves the efficiency of tourism and hotel sectors through tactic collaboration and partnership. The second paper applies textmining of social media to understand cultural tourist typologies. Based on TripAdvisor reviews, the study proposes a four-step framework for classifying cultural tourists. More specifically, a term-weighting model is developed to calculate the

Yang Yang

yangy@temple.edu

Jason L. Stienmetz

j.stienmetz@surrey.ac.uk

1 Department of Tourism and Hospitality Management, Temple University, Philadelphia, USA

2 School of Hospitality and Tourism Management, University of Surrey, Surrey, UK 
possibility score of each tourist based on the keywords found in the review content. In tourism planning, a better understanding of tourist typology enables DMOs to design more tailored products and services to distinct segments.

As these articles demonstrate, the digitalization of all aspects of tourism value creation has created the opportunity for tourism planners to better understand perceptions, preferences, behavior, and evaluations of tourists as well as the business performance of tourism-related businesses in a single destination (Stienmetz and Fesenmaier 2013). The hype and hope of big data represent an unprecedented opportunity in tourism planning by providing more sophisticated, wider-scale and finer-grained understanding of tourism demand and supply at different geographic scales. Indeed, we expect that research leveraging big data will transform the future of tourism planning.

\section{References}

De Montjoye Y-A, Radaelli L, Singh VK (2015) Unique in the shopping mall: on the reidentifiability of credit card metadata. Science 347(6221):536-539

Hardy A, Hyslop S, Booth K, Robards B, Aryal J, Gretzel U, Eccleston R (2017) Tracking tourists' travel with smartphone-based GPS technology: a methodological discussion. Inf Technol Tour 17(3):255-274

Huertas A, Marine-Roig E (2016) User reactions to destination brand contents in social media. Inf Technol Tour 15(4):291-315

Mariani M, Baggio R, Fuchs M, Höepken W (2018) Business intelligence and big data in hospitality and tourism: a systematic literature review. Int J Contemp Hosp Manag 30(12):3514-3554. https://doi. org/10.1108/IJCHM-07-2017-0461

Pan B, Yang Y (2016) Monitoring and forecasting tourist activities with big data. In: Uysal M, Schwartz Z, Sirakaya-Turk E (eds) Management science in hospitality and tourism. Apple Academic, Waretown, pp 43-62

Stienmetz JL, Fesenmaier DR (2013) Traveling the network: a proposal for destination performance metrics. Int J Tour Sci 13(2):57-75

Xiang Z (2010) Modeling the persuasive effects of search engine results. Inf Technol Tour 12(3):233-248 